\title{
The Impact of Nautical Activities on the Environment -A Systematic Review of Research
}

\author{
Helena Ukić Boljat ${ }^{1, *(1)}$, Neven Grubišić ${ }^{2} \mathbb{D}$ and Merica Slišković ${ }^{1}$ \\ 1 Faculty of Maritime Studies, University of Split, 21000 Split, Croatia; merica@pfst.hr \\ 2 Faculty of Maritime Studies, University of Rijeka, 51000 Rijeka, Croatia; neven.grubisic@uniri.hr \\ * Correspondence: hukic@pfst.hr
}

Citation: Ukić Boljat, H.; Grubišić, N.; Slišković, M. The Impact of Nautical Activities on the Environment-A Systematic Review of Research. Sustainability 2021, 13, 10552. https:// doi.org/10.3390/su131910552

Academic Editor: Jelena Čulin

Received: 1 September 2021

Accepted: 20 September 2021

Published: 23 September 2021

Publisher's Note: MDPI stays neutral with regard to jurisdictional claims in published maps and institutional affiliations.

Copyright: (c) 2021 by the authors. Licensee MDPI, Basel, Switzerland. This article is an open access article distributed under the terms and conditions of the Creative Commons Attribution (CC BY) license (https:/ / creativecommons.org/licenses/by/ $4.0 /)$.

\begin{abstract}
As nautical tourism and recreational activities involving boats have become highly popular, research interest on various effects of nautical tourism is also increasing. This paper aims to analyze the main scientific contributions in the field of nautical tourism and its impact on the environment. The focus of the analysis is on the methods used to estimate and model recreational boating activities. Since nautical tourism plays a crucial role in the context of the growth and development of the economy, it is necessary to consider the environmental component of its development. The background objective of the paper is to provide a representation of environmental descriptors, i.e., to highlight in particular the environmental impact of nautical tourism. A search on the Web of Science Core Collection, touching on this topic, is composed of scientific papers published in the period 2010-2021. The papers examined are divided into five categories according to the impact of nautical tourism they study: Environmental, Economic, Social, Technical or Other. The results show that most papers were published in the area of environmental impacts of nautical tourism, with most papers examining invasive species, antifouling and impacts on species. The analysis showed that the negative impacts were mainly studied individually. Based on the analysis and evaluation of the scientific publications, a basic recommendation is given for the construction of a model to estimate recreational boating activities and its impact on the environment.
\end{abstract}

Keywords: recreational boating; environmental impact; scientific publications; Web of Science; review

\section{Introduction}

Tourism, and thus recreational boating, implies the movement of people through time and space. Understanding the flow of tourists through time and space, and the factors that influence the relationship between time and space, certainly has a profound impact on the planning and management of resources for tourism services. Tourism plays a crucial role in the growth and development of the national (world) economy, and as such it must follow the guiding principle of sustainable development. When its role is considered in the context of sustainable development through the 2030 Agenda for Sustainable Development, it is possible to see its contribution (directly or indirectly in all Sustainable Development Goals), but especially within goal 8 (inclusive and sustainable economic growth), goal 12 (sustainable consumption and production and goal 14 (sustainable use of oceans and marine resources). [1] Gathering knowledge about the fundamentals and impacts of tourism is the first step towards achieving the goals. The basic characteristics of tourism are certainly spatial factors, but the fact is that very little research has been conducted to study and model spatial behavior. $[2,3]$ The reason why there are very few studies in this area is the fact that it is extremely difficult to collect these data. [4] The same issue is with nautical tourism, i.e., recreational boating. [5] To date, three methods have been used to collect spatial data in the tourism/recreation sector: direct observation, tracking people using devices (e.g., mobile phones) and recording spatial movements by completing questionnaires. The direct observation method includes four key steps "identify, track, observe, map". [6] The 
problem with device monitoring is that, in addition to invading people's privacy, no answer can be obtained about the purpose of the trip, accompanying decisions and activities. The third method is a qualitative questionnaire that collects data about the tourist's movement in space. Compared with tracking road traffic and traffic planning, tracking the movement of ships through the Automatic Identification System (AIS) or GPS (Global Positioning System) is equivalent to counting road traffic. The count is then used for model calibration, comparing the data obtained from the model (4-step model) and the actual measured data. All the elements needed for travel demand assessment cannot be obtained only by measurements; it is necessary to use the questionnaires, interviews, cordon surveys, etc.

The aim of this paper is to give an overview of the methods used to estimate ship movements / trajectories, to evaluate them and to propose a basis for the construction of a model to estimate recreational boating activities and their impact on the environment. This is conducted using three approaches: (1) a structured literature review examining relevant terms included in titles and abstracts of scientific articles about leisure boating/recreational boating and model/modelling in the Web of Science Core Collection, (2) a detailed review of selected scientific articles and reports founded in the Web of Science Core Collection in the period 2010-2021 and (3) a detailed review of selected scientific articles and reports published on an estimation of vessel trajectories / movement patterns of large vessels (which are required to have an AIS).

The findings on large vessel motion pattern estimation are relevant in the context of modelling trajectories with AIS data, as nowadays many recreational vessels are being or already are equipped with trackers or AIS.

Moreover, the review of the projects and reports relevant for the exploration of the boating preferences and possible impact on the environment will be presented.

This review follows the preferred reporting items for systematic reviews and metaanalyses (PRISMA) guidelines [7].

\section{Evaluation of Recreational Boating Routes and Its Impact on the Environment}

\subsection{Review and Clasiffication of the Research}

Information on the distribution and intensity of recreational boating is the basis for managing environmental, safety and social impacts. [8] Why a particular vessel (sailors, tourist boaters, fishermen) chooses a particular route and what influences the choice of a particular route certainly depends on several different factors. Different research and studies have been conducted to monitor routes in recreational boating. As the review follows the PRISMA guidelines, the methodology used is presented in the PRISMA flow (Figure 1).

The number of scientific publications which assess the topic of modelling the maritime/marine transport/transportation/traffic, multimodal transport/transportation and recreational/leisure boating noted that this number has increased over the last decade. This can be illustrated by searching the Web of Science Core Collection (Figure 2). The search is performed using the string Topic, which searches title, abstract, author keywords and keywords plus. From the figure, it is clear that the number of studies which deal with modelling of recreational boating is still poor (the majority of the research is in the period of 2010-2021). Further, we examined the Web of Science categories in which the papers (which deal with recreational boating) are mainly published into the following categories: Environmental Sciences, Ecology, Marine Freshwater Biology, Oceanography, Water Resources, Geosciences Multidisciplinary, Biodiversity Conservation, Hospitality Leisure Sport Tourism, Environmental Studies, Engineering Civil, Fisheries, Sociology.

As the focus of this paper is recreational boating, upon general search, by reading abstracts of publications in period 2010-2021 which were filtered through Web of Science topic search and publication year, the author extracted 71 publications relevant to the field of modelling recreational boating and possible impact on the environment. The filtered publications (67 in total, 4 of them found to be irrelevant for the purpose of this research) were then examined in detail and the results can be found in Table 1. 
Table 1. Overview of publications which deals with recreational boating and its impact on environment.

\begin{tabular}{|c|c|c|c|}
\hline Authors & Origin & Research Area Group & $\begin{array}{l}\text { Methodology } \\
\text { Proposed/Used }\end{array}$ \\
\hline Gray, D.L.; et al. (2010) [9] & Canada & $\begin{array}{c}\text { Environmental (mapping and } \\
\text { zoning of Marine Protected } \\
\text { Areas-MPA) }\end{array}$ & $\begin{array}{c}\text { Recreation opportunity } \\
\text { spectrum (ROS) and models } \\
\text { of recreation conflict. }\end{array}$ \\
\hline $\begin{array}{c}\text { Acosta, H.; Wu, D.R.; Forrest, } \\
\text { B.M. (2010) [10] }\end{array}$ & / & $\begin{array}{l}\text { Environmental } \\
\text { (invasive species) }\end{array}$ & $\begin{array}{l}\text { Implementation of a fuzzy } \\
\text { expert system (FES) for } \\
\text { Non-Indigenous Species (NIS) } \\
\text { to assess the risk of invasion } \\
\text { in marine environments by } \\
\text { recreational boats. }\end{array}$ \\
\hline Mari, L.; et al. (2011) [11] & $\begin{array}{l}\text { Mississippi-Missouri river } \\
\text { system in North America }\end{array}$ & $\begin{array}{l}\text { Environmental } \\
\text { (invasive species) }\end{array}$ & $\begin{array}{c}\text { Ecohydrological model for the } \\
\text { invasion of inland waters by } \\
\text { the zebra mussel } \\
\text { Dreissena polymorpha }\end{array}$ \\
\hline Grossmann, M. (2011) [12] & $\begin{array}{l}\text { Spreewald, Federal State of } \\
\text { Brandenburg (Germany) }\end{array}$ & Economic & Travel cost methodology \\
\hline $\begin{array}{c}\text { Muirhead, J.R. and MacIsaac, } \\
\text { H.J. (2011) [13] }\end{array}$ & Ontario Lakes & $\begin{array}{c}\text { Environmental } \\
\text { (invasive species) }\end{array}$ & $\begin{array}{l}\text { Boosted regression for } \\
\text { gravity models. }\end{array}$ \\
\hline $\begin{array}{c}\text { Muirhead, J.R.; Lewis, M.A.; } \\
\text { MacIsaac, H.J. (2011) [14] }\end{array}$ & New York State, USA & $\begin{array}{c}\text { Environmental } \\
\text { (invasive species) }\end{array}$ & $\begin{array}{l}\text { Developed two-stage model } \\
\text { for the spread of } C \text {. pengoi }\end{array}$ \\
\hline David, J.A. (2012) [15] &.- & $\begin{array}{c}\text { Environmental } \\
\text { (underwater noise) }\end{array}$ & Theoretical approach \\
\hline $\begin{array}{l}\text { Chivers, C.; Leung, B. } \\
\text { (2012) [16] }\end{array}$ & Ontario, Canada & $\begin{array}{l}\text { Environmental } \\
\text { (invasive species) }\end{array}$ & $\begin{array}{l}\text { Comparison of two prominent } \\
\text { models (gravity models and } \\
\text { random utility models) for } \\
\text { predicting human } \\
\text { movement patterns. }\end{array}$ \\
\hline $\begin{array}{l}\text { Lacoursiere-Roussel, A.; et al. } \\
\text { (2012) [17] }\end{array}$ & Canada and New Zeland & Environmental (antifouling) & $\begin{array}{c}\text { Boosted Regression Tree } \\
\text { analysis }\end{array}$ \\
\hline Tett, P.; et al. (2012) [18] & Loch Fyne, Scotland & $\begin{array}{l}\text { Environmental (antifouling) } \\
\text { and Economic }\end{array}$ & $\begin{array}{l}\text { Application of Science and } \\
\text { Policy Integration for Coastal } \\
\text { System Assessment } \\
\text { (SPICOSA) "Systems } \\
\text { Approach Framework (SAF)" }\end{array}$ \\
\hline Hallac, D.E.; et al. (2012) [19] & $\begin{array}{l}\text { Florida Bay, Everglades } \\
\text { National Park, USA }\end{array}$ & $\begin{array}{c}\text { Environmental } \\
\text { (impact on seagrass) }\end{array}$ & $\begin{array}{c}\text { prop-scarring analyses by } \\
\text { using aerial imagery, } \\
\text { statistical model development }\end{array}$ \\
\hline $\begin{array}{l}\text { Fujitani, M.L.; Fenichel, E.P.; } \\
\text { Torre, J.; Gerber, L.R. } \\
\text { (2012) [20] }\end{array}$ & Gulf of California, Mexico & $\begin{array}{l}\text { Environmental (impact on } \\
\text { fisheries) and Social }\end{array}$ & $\begin{array}{l}\text { Linear regression, discrete } \\
\text { choice model }\end{array}$ \\
\hline $\begin{array}{c}\text { Kang, N.S.; Yoon, H.H.; Shin, } \\
\text { I.S. (2013) [21] }\end{array}$ & / & Tehnical & $\begin{array}{c}\text { Development of a leisure boat } \\
\text { simulator (mathematical } \\
\text { model and algorithm for the } \\
\text { movement of a } \\
\text { recreational boat) }\end{array}$ \\
\hline Murray, C.C.; et al. (2013) [22] & British Columbia & $\begin{array}{c}\text { Environmental } \\
\text { (invasive species) }\end{array}$ & Questionnaire-based model. \\
\hline Lorenz, S.; et al. (2013) [23] & River Spree, Germany & $\begin{array}{c}\text { Environmental } \\
\text { (self-purification activity) }\end{array}$ & $\begin{array}{l}\text { Experiments on site (use of } \\
\text { recreational boat, cameras and } \\
\text { experimental mussels) }\end{array}$ \\
\hline Diedrich, A.; et al. (2013) [24] & Balearic Islands & $\begin{array}{l}\text { Environmental (anchoring } \\
\text { and Posidionia oceanica) }\end{array}$ & Classification tree method \\
\hline
\end{tabular}


Table 1. Cont.

\begin{tabular}{|c|c|c|c|}
\hline Authors & Origin & Research Area Group & $\begin{array}{l}\text { Methodology } \\
\text { Proposed/Used }\end{array}$ \\
\hline $\begin{array}{l}\text { Longley, K.; Lipsky, A. } \\
\text { (2013) [25] }\end{array}$ & Massachusetts & $\begin{array}{c}\text { Environmental } \\
\text { (cumulative impact) }\end{array}$ & $\begin{array}{l}\text { Cumulative impact model } \\
\text { which runs on GIS software } \\
\text { GRASS v. } 6.3\end{array}$ \\
\hline $\begin{array}{c}\text { Jett, J.; Thapa, B.; Swett, R. } \\
\text { (2013) [26] }\end{array}$ & St. Johns River in Florida & $\begin{array}{c}\text { Environmental (impact of } \\
\text { vessel speed on animals) and } \\
\text { Social (attitudes of boaters). }\end{array}$ & $\begin{array}{l}\text { Experiment on site (field } \\
\text { observation), mail survey; }\end{array}$ \\
\hline $\begin{array}{l}\text { Farr, M.; Stoeckl, N.; Sutton, S. } \\
\text { (2014) [27] }\end{array}$ & Townsville, Great Barrier Reef & Social & $\begin{array}{l}\text { Hurdle approach, two-stage } \\
\text { model }\end{array}$ \\
\hline $\begin{array}{l}\text { Loomis, J.; McTernan, J. } \\
\text { (2014) [28] }\end{array}$ & Poudre River in Colorado & Economic & $\begin{array}{l}\text { Recreation Demand and } \\
\text { Contingent Valuation } \\
\text { Methods (CVM) }\end{array}$ \\
\hline Raffaele, G. (2014) [29] & / & Other & $\begin{array}{l}\text { Development of statistical } \\
\text { tool-nomogram of } \\
\text { Port Dynamism. }\end{array}$ \\
\hline $\begin{array}{c}\text { Roe, P.; Hrymak, V.; } \\
\text { Dimanche, F. (2014) [30] }\end{array}$ & Ireland & Environmental & $\begin{array}{l}\text { Three stage model: risk } \\
\text { assessment, risk evaluation } \\
\text { and risk management }\end{array}$ \\
\hline Pieralice, F.; et al. (2014) [31] & $\begin{array}{l}\text { Eastern Ligurian sea } \\
\text { (Northern Italy) }\end{array}$ & $\begin{array}{l}\text { Environmental (anchoring) } \\
\text { and Tehnical }\end{array}$ & $\begin{array}{l}\text { A semi-automatic method, } \\
\text { statistical model to produce } \\
\text { maps of the spatial and } \\
\text { temporal distribution density } \\
\text { of anchored boats. }\end{array}$ \\
\hline $\begin{array}{l}\text { Davidson, A.D.; Fusaro, A.J.; } \\
\text { Kashian, D.R. (2015) [32] }\end{array}$ & Great Lakes & $\begin{array}{l}\text { Environmental } \\
\text { (invasive species) }\end{array}$ & $\begin{array}{c}\text { Empirical mapping } \\
\text { tool developed }\end{array}$ \\
\hline $\begin{array}{l}\text { Wittmann, M.E.; et al. } \\
\text { (2015) [33] }\end{array}$ & Lake Tahoe & $\begin{array}{l}\text { Environmental } \\
\text { (invasive species) }\end{array}$ & $\begin{array}{l}\text { Experiments in the field (use } \\
\text { of recreational boater survey } \\
\text { and measurement of wave } \\
\text { motion), statistical methods. }\end{array}$ \\
\hline $\begin{array}{l}\text { Cui, Y.; Chang, W.H.; } \\
\text { Mahoney, E. (2015) [34] }\end{array}$ & / & Economic and Social & $\begin{array}{l}\text { Economic impact spending } \\
\text { framework for different types } \\
\text { of recreational navigation }\end{array}$ \\
\hline $\begin{array}{l}\text { Lee, D.E.; Du Preez, M. } \\
\text { (2015) [35] }\end{array}$ & $\begin{array}{c}\text { Sundays River Estuary, } \\
\text { Eastern Cape, South Africa }\end{array}$ & $\begin{array}{l}\text { Environmental, Social } \\
\text { and Economic }\end{array}$ & $\begin{array}{c}\text { Applying a } \\
\text { choice-experiment-choice } \\
\text { model to estimate people's } \\
\text { preferences for less } \\
\text { boat congestion }\end{array}$ \\
\hline $\begin{array}{l}\text { Morandi, M.J.; et al. } \\
\text { (2015) [36] }\end{array}$ & Great Lakes & $\begin{array}{l}\text { Environmental } \\
\text { (invasive species) }\end{array}$ & $\begin{array}{c}\text { Gravity model framework, } \\
\text { development of a recreational } \\
\text { boater spread model }\end{array}$ \\
\hline $\begin{array}{l}\text { Lee, D.E.; Hosking, S.G.; Du } \\
\text { Preez, M. (2015) [37] }\end{array}$ & $\begin{array}{l}\text { Kromme River Estuary, } \\
\text { Eastern Cape. }\end{array}$ & $\begin{array}{l}\text { Environmental, Social } \\
\text { and Economic }\end{array}$ & $\begin{array}{l}\text { Application of a } \\
\text { choice experiment }\end{array}$ \\
\hline $\begin{array}{l}\text { Stewart-Koster, B.; Olden, J.D.; } \\
\text { Johnson, P.T.J. (2015) [38] }\end{array}$ & $\begin{array}{l}\text { water bodies in Wisconsin } \\
\text { and Michigan }\end{array}$ & $\begin{array}{l}\text { Environmental } \\
\text { (invasive species) }\end{array}$ & $\begin{array}{c}\text { Development of spatial } \\
\text { graphs, use of logistic } \\
\text { generalized additive models. }\end{array}$ \\
\hline Ray, C.; et al. (2015) [39] & / & Other & $\begin{array}{l}\text { Methodological approach to } \\
\text { modelling, analysis and } \\
\text { detection of new } \\
\text { maritime risks. }\end{array}$ \\
\hline $\begin{array}{l}\text { Gon, M.; Osti, L.; Pechlaner, H. } \\
\text { (2016) [40] }\end{array}$ & north part of the Adriatic Sea & Social & Cluster analysis \\
\hline
\end{tabular}


Table 1. Cont.

\begin{tabular}{|c|c|c|c|}
\hline Authors & Origin & Research Area Group & $\begin{array}{l}\text { Methodology } \\
\text { Proposed/Used }\end{array}$ \\
\hline Ferrario, J.; et al. (2016) [41] & Italy & $\begin{array}{l}\text { Environmental (invasive } \\
\text { species and antifouling) }\end{array}$ & Fuzzy logic approach \\
\hline $\begin{array}{l}\text { Pennino, M.G.; Roda, } \\
\text { M.A.P.; Pierce, G.J.; Rotta, A. } \\
\text { (2016) [42] }\end{array}$ & $\begin{array}{l}\text { Archipelago de La } \\
\text { Maddalena (Italy) }\end{array}$ & $\begin{array}{l}\text { Environmental } \\
\text { (impact on dolphins) }\end{array}$ & $\begin{array}{l}\text { Hierarchical Bayesian } \\
\text { approach (a Poisson model } \\
\text { with log-linear intensity. }\end{array}$ \\
\hline Ziv, G.; et al. (2016) [43] & $\begin{array}{l}\text { eight River Basin Districts } \\
\text { (RBDs) in England }\end{array}$ & $\begin{array}{l}\text { Environmental (water } \\
\text { quality) }\end{array}$ & $\begin{array}{l}\text { Statistical analysis, null } \\
\text { model of the predicted } \\
\text { percentage } \\
\text { of visits }\end{array}$ \\
\hline $\begin{array}{l}\text { Midwood, J.D.; et al. } \\
\text { (2016) [44] }\end{array}$ & Lake Ontario & $\begin{array}{l}\text { Environmental } \\
\text { (invasive species) }\end{array}$ & $\begin{array}{l}\text { Boosted regression tree } \\
\text { model }\end{array}$ \\
\hline $\begin{array}{l}\text { Curtis, J.; Hynes, S.; Breen, } \\
\text { B. (2017) [45] }\end{array}$ & Ireland & $\begin{array}{l}\text { Environmental and Social } \\
\text { (water quality) }\end{array}$ & Random utility model \\
\hline Viana, D.; et al. (2017) [46] & $\begin{array}{l}\text { Channel Islands National } \\
\text { Marine Sanctuary, USA }\end{array}$ & Social and Environmental & Random utility model \\
\hline Daehne, D.; et al. (2017) [47] & Germany & Environmental (antifouling) & $\begin{array}{l}\text { On-site sample survey, } \\
\text { marina survey. }\end{array}$ \\
\hline Leposa, N. (2017) [48] & Sweden (west coast) & Social and Environmental & $\begin{array}{l}\text { Mixed-methods approach } \\
\text { (consumer value theory } \\
\text { (CVT); motivation- } \\
\text { opportunity-ability } \\
\text { (MOA) model. }\end{array}$ \\
\hline $\begin{array}{l}\text { Chivers, C.; Drake, D.A.R.; } \\
\text { Leung, B. (2017) [49] }\end{array}$ & Ontario & $\begin{array}{c}\text { Environmental (washing of } \\
\text { hull-prevention of invasive } \\
\text { species) and Economic } \\
\text { (fees) }\end{array}$ & $\begin{array}{l}\text { Production-constrained } \\
\text { gravity models, combined } \\
\text { model for estimating the } \\
\text { effect of management } \\
\text { options on behavior change. }\end{array}$ \\
\hline $\begin{array}{l}\text { Hotaling-Hagan, A.; Swett, } \\
\text { R.; Ellis, L.R.; Frazer, T.K. } \\
\text { (2017) [50] }\end{array}$ & Estero Bay, Florida & $\begin{array}{l}\text { Environmental (impact on } \\
\text { seagrass and its restoration) }\end{array}$ & $\begin{array}{l}\text { Geospatial } \\
\text { modeling technique }\end{array}$ \\
\hline $\begin{array}{l}\text { Itami, R.M.; Gimblett, R.; } \\
\text { Poe, A. (2017) [51] }\end{array}$ & $\begin{array}{l}\text { Melbourne, Australia, and; } \\
\text { a vast wilderness waterway } \\
\text { in Alaska. }\end{array}$ & Social, Economic, Technical & $\begin{array}{l}\text { Proposition of "Level of } \\
\text { Sustainable Activity" } \\
\text { (LSA) framework }\end{array}$ \\
\hline $\begin{array}{l}\text { Jain-Schlaepfer, S.M.R.; et al. } \\
\text { (2017) [52] }\end{array}$ & $\begin{array}{c}\text { Lake Opinicon, } \\
\text { Ontario, Canada. }\end{array}$ & $\begin{array}{l}\text { Environmental (impact of } \\
\text { motorboats on turtles) }\end{array}$ & $\begin{array}{l}\text { Field and laboratory data, } \\
\text { predictive modelling }\end{array}$ \\
\hline Parsons, G.R. (2017) [53] & / & Economic & $\begin{array}{l}\text { Application of the random } \\
\text { utility-based model }\end{array}$ \\
\hline Montes, N.; et al. (2018) [54] & southeastern United States & $\begin{array}{l}\text { Social and Environmental } \\
\text { (impact on mammals) }\end{array}$ & Theory of planned behavior \\
\hline $\begin{array}{l}\text { Han, J.H.; Oh, C.O. } \\
\text { (2018) [55] }\end{array}$ & Michigan, USA & Environmental and Social & $\begin{array}{l}\text { Direct acyclic graph } \\
\text { (DAG) theory. }\end{array}$ \\
\hline $\begin{array}{l}\text { Montes, N.; Swett, R.; } \\
\text { Ahrens, R. (2018) [56] }\end{array}$ & $\begin{array}{l}\text { offshore waters off the coast } \\
\text { of Northeast Florida }\end{array}$ & Other & $\begin{array}{c}\text { Testing of different } \\
\text { techniques in R: generalized } \\
\text { linear models (GLM) with a } \\
\text { Poisson distribution, a } \\
\text { negative binomial } \\
\text { distribution, generalized } \\
\text { additive models with } \\
\text { negative binomial link } \\
\text { (GAM), hurdle negative } \\
\text { binomial models, } \\
\text { zero-inflated negative } \\
\text { binomial models, and a } \\
\text { generalized linear mixed } \\
\text { effects modeling approach. }\end{array}$ \\
\hline
\end{tabular}


Table 1. Cont.

\begin{tabular}{|c|c|c|c|}
\hline Authors & Origin & Research Area Group & $\begin{array}{l}\text { Methodology } \\
\text { Proposed/Used }\end{array}$ \\
\hline Hunt, L.M.; et al. (2019) [57] & Ontario, Canada & $\begin{array}{l}\text { Social (site choices) and } \\
\text { Environmental }\end{array}$ & Two modelling approaches \\
\hline $\begin{array}{l}\text { Pelletier-Rousseau, M.; et al. } \\
\text { (2019) [58] }\end{array}$ & Atlantic coast of Canada & $\begin{array}{l}\text { Environmental } \\
\text { (invasive species) }\end{array}$ & $\begin{array}{l}\text { Predictive approach to } \\
\text { evaluate the relative } \\
\text { invasion hazard (boat } \\
\text { hazard model and score) }\end{array}$ \\
\hline Alvarez, S.; et al. (2019) [59] & southwest Florida & $\begin{array}{l}\text { Environmental (algae } \\
\text { bloom) and Economic }\end{array}$ & Random utility model \\
\hline $\begin{array}{l}\text { Hermannsen, L.; et al. } \\
\text { (2019) [60] }\end{array}$ & Inner Danish waters & Environmental (noise) & $\begin{array}{l}\text { Linear mixed-effect model } \\
\text { (GLMM), underwater noise } \\
\text { sampling on site }\end{array}$ \\
\hline $\begin{array}{c}\text { Abu Hanipah, A.H.; Guo, } \\
\text { H.R. (2019) [61] }\end{array}$ & Brunei River & Environmental (reaeration) & $\begin{array}{c}\text { Spatial analysis, predictive } \\
\text { equation }\end{array}$ \\
\hline $\begin{array}{l}\text { Bigerna, S.; Micheli, S.; } \\
\text { Polinori, P. (2019) [62] }\end{array}$ & $\begin{array}{c}\text { Regional Park of Trasimeno } \\
\text { Lake (ITALY) }\end{array}$ & $\begin{array}{l}\text { Environmental }\left(\mathrm{CO}_{2}\right) \\
\text { and social }\end{array}$ & $\begin{array}{c}\text { Contingent } \\
\text { valuation method }\end{array}$ \\
\hline $\begin{array}{l}\text { Johansson, L.; et al. } \\
\text { (2020) [63] }\end{array}$ & Baltic Sea & $\begin{array}{c}\text { Environmental } \\
\text { (emission, antifouling) }\end{array}$ & $\begin{array}{l}\text { Leisure Boating Emissions } \\
\text { and Activities Simulator } \\
\text { (BEAM) presented }\end{array}$ \\
\hline Dalton, T.; et al. (2020) [64] & Rhode Island (US) & $\begin{array}{l}\text { Social (impact of wind } \\
\text { farms on boating sector) }\end{array}$ & Mixed logit model \\
\hline $\begin{array}{c}\text { Marusic, E.; Soda, J.; Krcum, } \\
\text { M. (2020) [65] }\end{array}$ & Croatia & Economic & $\begin{array}{c}\text { Proposal of } \\
\text { Three-Parameter Model to } \\
\text { classify and sub-classify } \\
\text { each month during a } \\
\text { nautical season by the } \\
\text { variations in demand. }\end{array}$ \\
\hline Vieira, M.; et al. (2020) [66] & $\begin{array}{c}\text { Tagus estuary in Portugal } \\
\text { and the Öresund strait in } \\
\text { the Baltic Sea. }\end{array}$ & $\begin{array}{c}\text { Environmental } \\
\text { (underwater noise) }\end{array}$ & $\begin{array}{l}\text { A Hidden Markov Model } \\
\text { (HMMs) }\end{array}$ \\
\hline Alos, J.; et al. (2020) [67] & 然 & Environmental & $\begin{array}{l}\text { A Hidden Markov Model } \\
\text { (HMM) }\end{array}$ \\
\hline Parretti, P.; et al. (2020) [68] & $\begin{array}{c}\text { Portugal } \\
\text { (Azores and Madeira) }\end{array}$ & $\begin{array}{c}\text { Environmental } \\
\text { (invasive species) }\end{array}$ & $\begin{array}{l}\text { Fuzzy inference system for } \\
\text { risk assessment }\end{array}$ \\
\hline $\begin{array}{c}\text { Kuentzel, W.F.; et al. } \\
\text { (2020) [69] }\end{array}$ & $\begin{array}{c}\text { Apostle Islands } \\
\text { National Lakeshore }\end{array}$ & Social & $\begin{array}{l}\text { Hierarchical linear } \\
\text { modeling (HLM) }\end{array}$ \\
\hline $\begin{array}{l}\text { Palomo, L.E.; et al. } \\
\text { Hernandez-Flores, A. } \\
\text { (2020) [70] }\end{array}$ & / & Environmental, social, other & $\begin{array}{l}\text { Spatial model and } \\
\text { decision theory }\end{array}$ \\
\hline $\begin{array}{l}\text { La Manna, G.; et al. } \\
(2020)[71]\end{array}$ & northwest Sardinia, Italy & $\begin{array}{c}\text { Environmental } \\
\text { (species distribution) }\end{array}$ & MaxEnt modeling approach \\
\hline $\begin{array}{l}\text { Lagerstrom, M.; et al. } \\
\text { (2020) [72] }\end{array}$ & $\begin{array}{c}\text { Baltic sea marinas } \\
\text { (Sweden and Finland) }\end{array}$ & Environmental (antifouling) & $\begin{array}{l}\text { Sampling on site, statistical } \\
\text { test of samples (ANOVA; } \\
\text { linear regression analysis) }\end{array}$ \\
\hline $\begin{array}{l}\text { Kendall, M.S.; et al. } \\
\text { (2021) [73] }\end{array}$ & southeastern USA & Technical and Other & Linear modelling approach \\
\hline $\begin{array}{l}\text { Chapagain, B.P.; et al. } \\
\text { (2021) [74] }\end{array}$ & USA & Social and Economic & Travel cost model \\
\hline Kao, S.Y.Z.; et al. (2021) [75] & Minessota, USA & $\begin{array}{l}\text { Environmental } \\
\text { (invasive species) }\end{array}$ & $\begin{array}{l}\text { Analytical approach, } \\
\text { predictive models to } \\
\text { capture boater patterns. }\end{array}$ \\
\hline
\end{tabular}




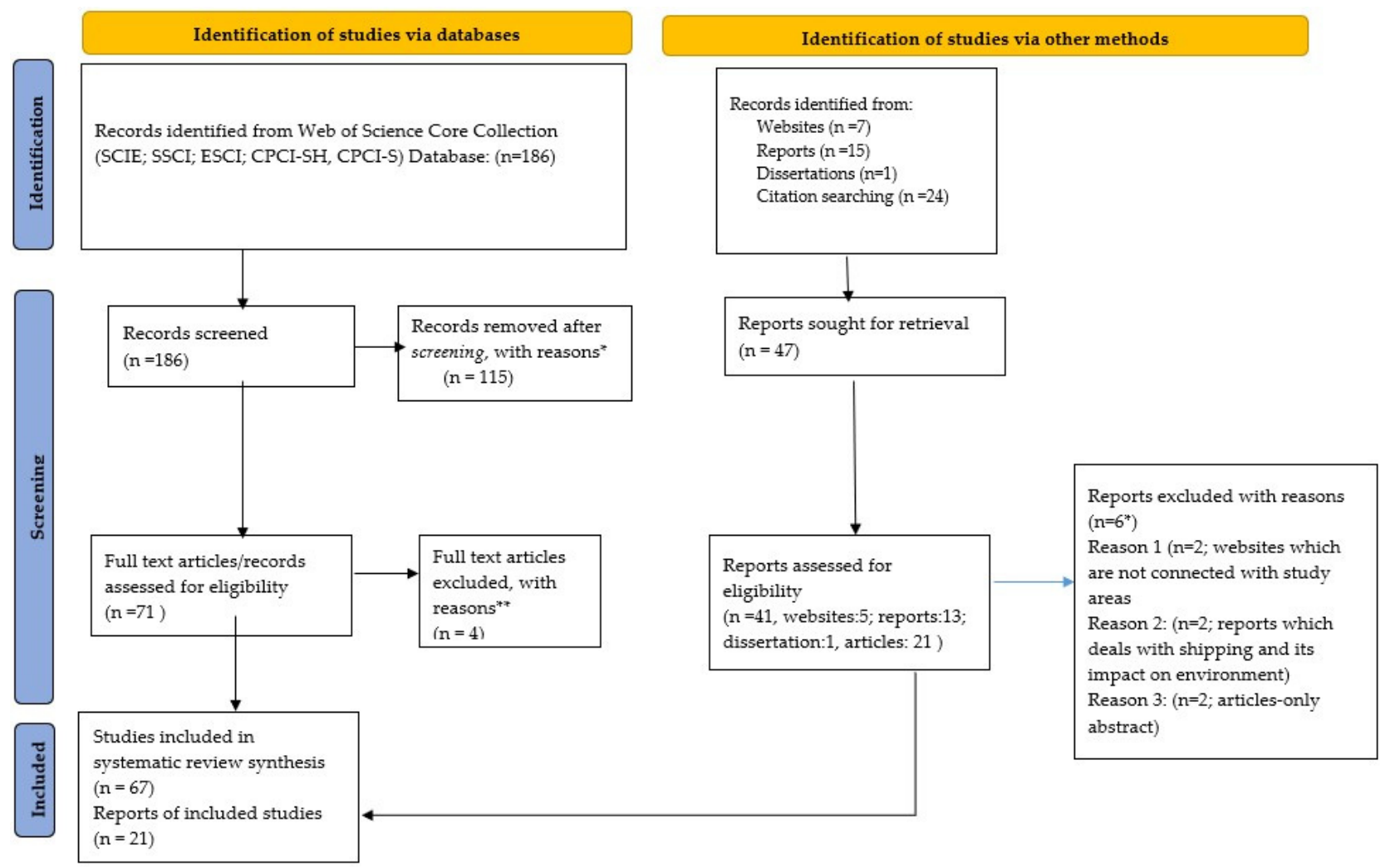

Figure 1. Preferred reporting items for systematic reviews and meta-analyses (PRISMA) analysis flow. * The exclusions correspond to the articles which were removed after reading abstracts as they were not relevant to the field of modelling recreational boating and possible impact on the environment. The excluded articles deals with adoption of electric service boats; power-to-gas model as support for recreational boating activities, ship building cost estimation for catamaran type, designing/modelling the leisure boats, modelling the internal combustion engine; examination of levels of electromagnetic fields from small boats, life jackets effectiveness in recreational boating, joystick steering in recreational boats, knowledge management in recreational boating industry; travel cost models in the context of fixed cost, management of users conflicts in reservoirs, reaeration of hypoxic weir pools, invasive species (other context than introduction by recreational boating), forecasting of wind speed, management strategies for the spread of invasive species, resiliency planning, Imputation of missing data from time-lapse cameras, ship induced waves, pontoon boats, seaweed tracking tools. ${ }^{* *}$ The exclusions correspond to the one project Biomares with aim to restore and manage the biodiversity, three articles dealing with fish pass and slide for recreational boats in one multipurpose structure; models of lake invisibility by a non-indigenous zooplankton. 


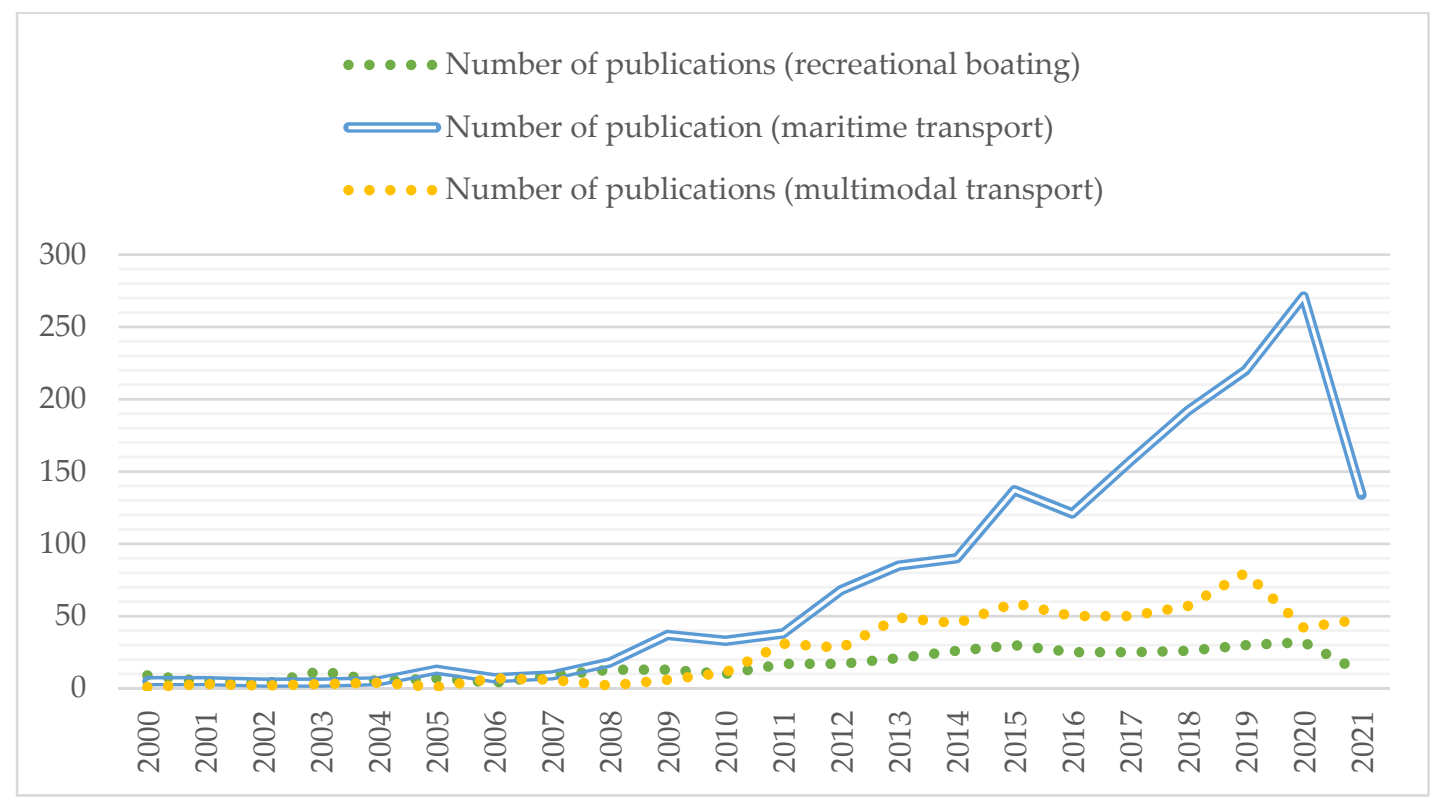

Figure 2. Comparison of studies of maritime transport, multimodal transport and recreational boating during 2000-2021 found on Web of Science in July, using TOPIC search: (1) (TS = ("boating" or "leisure boating" or "leisure boat*" or "recreational boating" or "recreational boat" $\left.{ }^{* \prime}\right)$ AND TS = ("model ${ }^{* \prime \prime}$ or "modelling"); (2) TS = ("maritime transport" or "maritime transportation" or "marine transport" or "marine transportation" or "maritime traffic" or "marine traffic") AND TS $=\left(\right.$ "model ${ }^{* \prime}$ or "modelling"); 3) TS $=($ "multimodal transport" or "multimodal transportation") AND TS = ("model*" or "modelling").

Articles are classified into five groups according to research field, origin (geographical), and methodology applied. Groups are: technical, economic, social, and environmental and others. The extended table with main topic/subject contribution can be found in the Supplementary Materials (Table S1).

The majority of the studies considered/examined the environmental impact of recreational boating ( 50 of them) (see Table 1 and Figure 3). Some of the articles examined two or three impact categories (usually a combination of social and environmental impacts). The most studied environmental impacts were the introduction of invasive species by recreational boating (17 of them); antifouling (5 articles); impacts on species (seagrass, whales, dolphins, turtles, P. oceanica-10 studies) and fisheries (1 study); underwater noise (3 studies); emissions (3 studies); anchoring impact ( 2 studies); water quality (2 studies); reaeration and self-purification (2 studies); mapping and zoning of MPA(1 study); cumulative impact (1 study); environmental sustainability (boat congestion) and environmental sustainable behavior (7 articles). By environmental category, social area/impacts were the most studied, including examining boaters' preferences in destination choice and their attitudes ( 8 articles), boaters and residents' perceptions of recreational boating tourism ( 7 articles); boaters characteristics ( 1 article), impacts of wind farms on recreational boaters ( 1 article) and distinguishing boating patterns of anglers and boaters ( 1 article). Travel cost methodology was presented in four studies $[12,28,53,74]$, while the estimation of the economic impacts of recreational boating activities was presented in [34]. Economic impacts were usually examined in combination with other impacts (social and environmental category). The combination of ecological and economic components is studied in five articles $[18,35,37,49,59]$. The study of demand for recreational boats in the nautical port sector through a three-parameter model is conducted in [65]. Furthermore, the technical component is studied in [21], where the concept study for the development of a recreational boat simulator is presented. The technical component is usually studied in combination with other impacts (social, economic, others). The authors [51] proposed a framework for determining capacity and management strategies for watercraft (combination of social, 
economic and technical components). Abrasion pressure due to mooring using a vessel detection algorithm in SAR images is studied in [31] (technical and environmental). A linear modelling approach to identify variables that have an impact on visitor use is presented in [73]. There are three papers in the "other" category $[29,39,56]$. These papers address various issues that are relevant to this area but can also be directly related to other impacts.

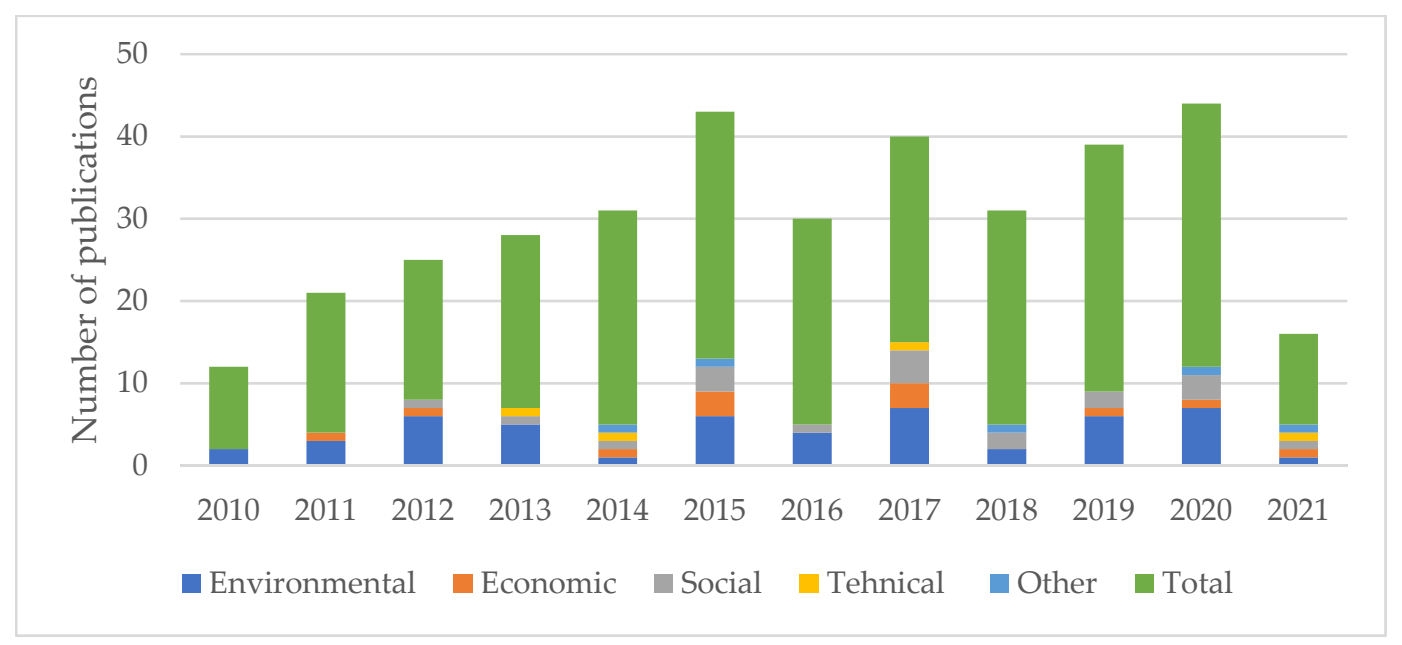

Figure 3. Relation of the total number of publication and impacts studied through filtered publications in period $2010-2021$.

If we look at the geographical distribution of the research, we can see that the majority of the research covers the territory of the United States and Canada, while some of them cover Europe (United Kingdom, Ireland, Italy, Sweden, Germany and Croatia). The geographical distribution is logical because in 2019, there were about 11.88 million recreational boaters registered in the United States and the majority of adults ( 87.3 million adults in 2014) participate in recreational boating activities [76]. On the other hand, in the Europe, the latest numbers show that there are about 6.3 million vessels, 4500 marinas and 1.75 million berths [77].

\subsection{Data Survey Methods}

From the analysis conducted in WoS, it is evident that the majority of research uses surveys/questionnaires to research boating routes, preferences, and behaviors [32,33,41, $45,49,50,54,56,62-64,74,75]$. In addition to the literature search on the Web of Science, the authors examined relevant research articles, reports, and projects that also address this context across different countries. The results of the various leisure studies are presented below.

In the United States of America area, there are several studies that deal with recreational boating and boating movement mapping. The first survey of the program, the National Recreational Boating Safety (RBS), was conducted in 2002, followed by three other surveys in 2011, 2012 and 2018. The National Recreational Boating Safety Survey reports provide a scientific assessment of the number of recreational boater characteristics, the number of different types of recreational boats and the size of the boating population [78-81].

Since the purpose of the previously mentioned reports is to assume safer boating behavior, the data research presented by $[82,83]$ aims to provide information on the behavior and spatial patterns of offshore recreational boaters in the Northeast Florida and Southeast Georgia region to determine impacts on the conservation of the North Atlantic right whale.

In addition, the authors [84-86] provide basic information on nearshore recreational activities in their paper on Cork Harbor. In the paper series, the authors present results of the collaborative research initiative-Coastal Research and Policy Integration (COREPOINT), which involves planners and scientists from local governments. Under this initiative, efforts have been made to improve understanding of current levels of recreational activity 
and the planning and management implications associated with potential increases above current levels.

In Sweden, the first survey of boating and its use was conducted in 2004. A follow-up survey targeting a sample representative of the total population was conducted in 2010 and 2015. The basic purpose of the Recreational Boating Survey (RBS) was to provide facts about boating and boats [87]. The results of this research were used to build the new simulation model Leisure Boating Emissions and Activities Simulator (BEAM) [63]. The model, BEAM, which uses a wide range of information sources and data processing techniques, was created to evaluate recreational boating activities and emissions for $\mathrm{PM}_{2.5}$, $\mathrm{NOx}$, non-methane $\mathrm{VOC}_{\mathrm{s}}\left(\mathrm{NMVOC}_{\mathrm{s}}\right), \mathrm{CO}$ and selected antifouling paint (AFP) (copper and zinc). This modeling approach, used for recreational boats on the Baltic Sea, considered the temporal and spatial distribution of emissions. The model combines recreational boating characteristics (data from the RBS), a derived temporal profile (based on data from AIS for the Baltic Sea during 2014-2016), and geographic distribution (a geographic distribution of marinas). According to the literature, this is the first study to address the multiple impacts of recreational boating on the environment (emissions and antifouling paint).

In the Republic of Croatia, there are two studies investigating the attitudes and consumption of nautical tourism guests in 2012 and 2017 [88,89]. The studies were conducted by interviewing 1666 boaters who visited Croatian marinas and ports open to public transport.

\subsection{Environmental Issues_-Highlighted Research}

Boating and shipping operations and associated infrastructure and activities have various environmental impacts that include physical (anchoring and mooring activities, groundings, collisions and disturbances, garbage and debris, propeller wash-off and vessel wake), chemical (antifouling agents, gas emissions, hydrocarbons, vessel maintenance and ship breaking, sewage, trace metals) and biotic factors (alien species, light pollution) [90]. Although structured literature review shows that the majority of research addresses the environmental effects of recreational activities, there is still a lack of studies on the environmental impacts and effects of boating [91].

The first report aimed at identifying and assessing the environmental impact of nautical activities was published in 2007 by European Confederation from Nautical IndustriesECNI [92]. The second subsequent report, introducing the life cycle approach to assessing the environmental impacts of boating, was published in 2009 [93]. This report highlights the need to distinguish recreational boating from commercial maritime transport. Maritime transport relies on significantly different technologies and operations, and their respective environmental impacts are different. Furthermore, according to [94], recreational boating and other water-based recreational activities have low environmental impacts (less than $1 \%$ of the total pollution of the marine environment).

In considering waste, a large amount of waste comes from land-based activities, but a considerable amount comes from boat and ship operations [90].

In terms of air pollution, emissions from recreational boat engines account for only $0.56 \%$ of total emissions from human activities, and $1.65 \%$ of emissions from road transport [93]. Since the above metrics date back a decade, it is interesting to see new findings regarding leisure boat emissions and how they compare with commercial shipping. The authors report that emissions of some pollutants emitted by leisure boats are significant compared with commercial shipping [63]. The year observed is 2014, and the study area is Baltic Sea. NMVOC emission factors for leisure boats are estimated to be significantly greater, equal to $160 \%$ compared with commercial shipping. Moreover, CO emissions from leisure boats are equal to $70 \%$ of registered vessel emissions. The modeled results for $\mathrm{NOx}$ and $\mathrm{PM}_{2.5}$ from leisure boats are less significant. The authors emphasize the relative importance of leisure boat emissions compared with commercial shipping during the summer months. In July 2014, results for leisure boats showed 500\% greater emissions for NMVOC, $140 \%$ greater CO emissions and $80 \%$ greater zinc emissions compared with 
commercial shipping [63]. Interesting results regarding greenhouse gas (GHG) emissions from marine tourism for the Australian region were presented in [94]. Through conducted interviews and in situ audits with boat operators, the authors estimate GHG emissions for the boating sector to be 70,000 tons of $\mathrm{CO}_{2}$. This means that if a tourist travels on a boat with a diesel engine, the authors estimate an average emission of $61 \mathrm{~kg} \mathrm{CO}_{2}$-e per tourist, or $27 \mathrm{~kg} \mathrm{CO}$-e for a trip on a boat with a petrol engine.

Another important pollutant to consider in the context of recreational boating is antifouling agents and trace metals. The distributions of trace metals (TM), organic carbon, SPM and physicochemical parameters for the estuary Krka River were studied in [95]. The results of the study show that in some parts of Šibenik Bay, the concentrations of copper are 10-20 times higher than in areas of the estuaries where there is no influence of ships. The authors highlight that the non-conservative behaviour of $\mathrm{Zn}, \mathrm{Cd}, \mathrm{Pb}$ and $\mathrm{Cu}$ in the brackish water layer (plume) was mainly caused by their inputs from recreational activities (recreational boats, nautical marinas and harbour). The elevated copper concentration originated from antifouling paints used as biocides for nautical vessels. Additional studies of environmental impacts, i.e., the influence of navigation in the Krka estuary were carried out by the project Nautical Tourism Ecological Footprint in MPAs (NaTEF) [96]. The objectives of NaTEF include: measuring the intensity (including temporal and spatial distribution) of maritime traffic, monitoring the copper content in the surface water of the Krka Mouth and determining the correlation between copper distribution and the number of boats in the estuary. The researchers also intend to extend the footprinting analysis to other aspects such as underwater noise, grey water, black water, bilge, etc. $[96,97]$. In addition, according to field research, concentrations of copper $(\mathrm{Cu} 2+)$ released from antifouling coatings of small to medium-sized anchored vessels range from 8.2 $\mu \mathrm{g} \mathrm{cm}^{-2} \mathrm{day}^{-1}$ to $18-22 \mu \mathrm{g} \mathrm{cm}^{-2} \mathrm{day}^{-1}[98,99]$. Since small to medium-sized boats generally operate in shallow areas near harbors and coasts (where water exchange is limited), they pose a greater threat to the marine environment than larger vessels [90].

Physical damage to nearshore marine ecosystems and seabed habitats is often caused by recreational boat anchoring and mooring. The aspect of anchoring of nautical tourism vessels and its influence on habitat destruction of Posidonia oceanica was studied in $[100,101]$. In their study, the authors emphasized the importance of environmental education regarding correct anchoring practices and anchor types. Ecological mooring systems, which provide permanent lines that allow boaters to fix their position without dropping the anchor, are a great measure to reduce the pressure of free anchoring and mooring in shallow meadows [102]. To quantify the effects of boat traffic, docks and mooring buoys on vegetation abundance, Sagerman et al. [103] presented the first systematic review and meta-analysis. Their results show a relationship between boat traffic and significant declines in submerged vegetation.

The review of environmental descriptors related to recreational boating shows that none of the studies cover the problem of sewage in terms of estimation/quantification. A qualitative risk assessment of marine black water pollution from specific types of ships at a specific location is carried out in [104]. The results obtained show that the greater risk of marine pollution by black water in coastal areas is posed by smaller ships and recreational vessels than in the navigation and stay of large cruise ships. Further, according to [90], boating and shipping related sewage is generally considered as a cumulative impact (together with land-based activities). Some of them [96,97] recognize the threat of gray water, black water and bilge, and plan to extend the research to these areas as well. The problem of noise pollution from recreational engines is only beginning to be researched. The calculation of air emissions from recreational boats is presented only in [63]. Most of the research is related to non-native species, which are well studied so far. Furthermore, the problem of anchoring is recognized as a threat and new solutions (environmentally friendly anchoring) to this issue are presented. Examples of good practices can be seen in $[105,106]$. 


\subsection{Vessel Tracking Based on AIS Data}

Monitoring and determining the trajectory of ships is a topic that has been well studied in the literature, especially in the context of navigational safety. Trajectory analysis reveals the pattern in ship movement. A simple and effective method for visualizing ship motion patterns is Traffic Density Maps (TDM) [107]. The observed movement patterns can reveal the presence of congested areas and thus serve as a support in the field of maritime surveillance and management. Furthermore, the comprehensive map of global shipping density is of key importance in the context of maritime situational awareness (MSA), which is composed of both vessel and traffic density [108].

One of the basic macroscopic characteristics of traffic (road) flow is traffic density and is used in the evaluation of traffic performance from the point of view of users and system operators [109]. Similarly, it is important to give a clear definition of vessel density. The EU-funded European Marine Observation and Data Network (EMODnet) aims to make previously scattered European marine data available through a single portal. EMODnet provides vessel density maps of European waters on a fully documented, bespoke methodology, which differs from the methods commonly used to calculate vessel density [110]. EMOdnet defines the vessel density as how many vessels one expects to find within the area of reference during a given time period. The main problem is the fact that actual number of vessels within that area is never constant over time due to ships ${ }^{\prime}$ movement at different speeds. Accordingly, the vessel density should be the expected number of ships in that area, i.e., the average number of ships in that area, taken from a large number of samples in time [110].

Furthermore, there is no internationally agreed methodology/standard used for the creation of TDM. Most methodologies are based on grid-based approaches, where the monitored area is divided into cells to create a spatial grid. This methodology is also approved by the High-Level Steering Group for Governance of the Digital Maritime System and Services (HLSG). The methodology used for density plotting is based on calculating the number of routes recorded for a given vessel within a given cell of the grid during a given time period [107].

In related research, several methods/techniques have dealt with the representation of maritime traffic from self-report data. Such methods can be classified into two main groups: Spatial grid techniques and spatio-temporal techniques. The general advantage of spatial grid techniques is the fast approach to detect and visualize low-level maritime layers. As the scale of the area to be monitored increases, a large computational burden occurs, which is the main shortcoming of spatial grid techniques. Moreover, due to aggregation and manipulation, it is difficult to detect structured anomalies (e.g., cruise start/stop) [111].

Several research by using raw maritime traffic data deal with modelling and recognizing ship patterns based on spatio-temporal data mining techniques. Some of them are presented below.

There is series of work by Pallota et al. [111-114] in which authors present methodology, called TREAD (Traffic Route Extraction and Anomaly Detection). In [113], the authors present an unsupervised and incremental learning approach for extracting maritime motion patterns from raw data. Furthermore, in [111], the authors propose an automatic generation of geographic maritime networks. The use of historical AIS data is proposed to detect and synthesize de facto maritime routes to automatically represent maritime traffic in a graphbased topology. This approach follows the idea that ships typically follow some de facto standardized sea routes for various reasons, such as protected sea areas where maritime traffic is restricted or prohibited, regulated traffic through highly congested areas, known security threats, due to weather and sea conditions, or for fuel efficiency reasons. In [111], the authors propose a new method that follows on from the method previously proposed in [113]. The innovations concern the distinction and separation between semantic routes and routes, and the introduction of a new method for detecting changes in vessel behavior based on the algorithm of Douglas and Peucker. Most of the analyzes of maritime traffic carried out so far also include data collected through Automatic Identification System 
(AIS), which is mandatory for ships of 300 gross tons or more on international voyages and 500 gross tons or more for the carriage of cargo not in international waters, as well as for passenger ships. Via AIS, it is possible to obtain information on the ship's call sign, the name of the ship, the position, the type of ship and the cargo [113]. In this context, there are many different works that deal with the analysis and collection of data by AIS systems in different domains. Wu et al. [115] produced maps of ship density, including maps of ship and traffic density, using 20 billion different datasets from AIS (over a period of more than 2.5 years). Willems et al. [116] presented a method to compute and visualize moving objects (the speed of the ship is taken into account). In order to better compress ship trajectory data in terms of compression time and efficiency, Zhao and Shi [117] presented a method to simplify ship trajectories by considering the course of the track point. The proposed method is based on the Douglas-Peucker algorithm and was implemented on one month of real AIS data on the island Zhou Shan.

\section{Discussion}

\subsection{Discussion of Recent Related Work}

According to the background research, there is not yet an internationally agreed methodology/standard for the creation of traffic density maps. Most of the methods are based on grid-based approaches (the monitored area is divided into cells to create a spatial grid) [107], while some of them use spatio-temporal approaches [111-114].

In this context, the available data from AIS, which were specifically used to create a map of the density of maritime traffic, are of great help. The methods commonly used in Big Data analysis and processing belong to the data mining techniques. The methods developed for data analysis and creation of maritime traffic density maps can certainly be used in the model to estimate recreational boating activities, especially due to the fact that large motor yachts and larger vessels used for recreational purposes have been/are already supplied with AIS. To date, questionnaire and interview methods have been used to identify itineraries and determine boaters' preferences, in addition to observational methods $[32,33,41,45,49,50,54,56,62-64,74,75]$. The above methods are definitely time consuming, costly and largely depend on the boater's memory/knowledge of the last route he was on. On the other hand, these methods are the only way to identify preferences and the reasons why a boater chooses a particular route and why they are interested in a particular destination. The knowledge hidden in these data is used to shape the future supply of a particular destination, but perhaps also potential constraints on the destination (e.g., national parks, nature preserves, and reserves, which are usually the most attractive, are the most crowded).

Furthermore, when considering the potential environmental footprint of nautical tourism, it is important to note that the only work by the authors [63] summarizes several negative environmental impacts of nautical tourism. Similarly, the review of previous studies shows that some environmental descriptors have been mainly/individually studied and no work has explored/included the impact of black water, which is certainly one of the more significant factors (especially in areas along the coast) when we talk about nautical tourism. The work [104] suggests that nautical tourism vessels belong to a category with high and medium pollution risk in black water.

Some ecological descriptors have been identified in recent years and their potential negative impacts are only beginning to be explored (noise, black water, emission of harmful gases).

\subsection{General Remarks}

Considering the specificity of recreational boating, the main purpose of this paper was to provide an overview of methods and models dealing with recreational boating and its impact on the environment, with the aim of identifying bases for the construction of a model to estimate boating activities and the footprint of nautical tourism. 
Determining the routes of individual vessels is crucial in the field of maritime spatial planning, especially when there are certain areas that are sensitive or are planned for a different purpose [8]. As the vessels in nautical tourism are not obligated to have AIS, the pattern of movement of vessels between marinas and ports is neither noted nor known. The reasons why an individual vessel (charterer, tourist or fisherman) selects a particular route and what has an impact on the individual route choice certainly depends on a number of different factors.

Studying the travel needs and determining the movement pattern (route) of small ships is quite difficult, especially for ships that are chartered. Some of the data (routes) can be obtained via GPS locator installed on board. Nowadays, tracking a fleet of ships, yachts or any floating objects has become quite easy, as the installation of high-quality GPS locators on ships based on the GPS satellite positioning system and GSM/GPRS network can determine the position at any time. The main problem is the fact that a large number of charter agencies have not introduced locating of their own vessels, as this determination is quite expensive, especially if they have a large number of vessels in their fleet.

From all of the above, it is necessary to point out and suggest the following:

- Tracking the routes of recreational boats is challenging (there is no single method that is sufficient on its own). To collect information on routes and movements of small vessels, several methods and techniques need to be combined: trackers installed on board, data from AIS, surveys, interviews, observation methods (video surveillance, drones). In order to build a model to estimate recreational boat activities, it is desirable to collect and include as much data as possible from the tracker, as these data are credible and include the vessel's position, coordinates (latitude and longitude) and its speed in well-defined time horizons. The potential problem with collecting this type of data may be the fact that not all charter agencies are willing to share their data, as well as the fact that the majority of charter agencies have not implemented tracking of their own vessels, especially if they have a large number of vessels in their fleet.

- The attractiveness of the individual location and the reasons why boaters choose a particular destination can only be determined through qualitative research (questionnaires, interviews). Based on the collected data, following the methodology presented in [118], the attractiveness of individual sites can be determined by using a multicriteria analysis. These findings can be used to support decisions on the creation of a new supply or to set individual restrictions to protect a single site.

- When modelling the potential ecological footprint of nautical tourism using the descriptors already presented [63], it is necessary to include black water.

This review must be seen in the light of some limitations. The first relates to single review of titles and abstracts. According to [119], single-reviewer abstract screening missed $13 \%$ of relevant studies, while dual-reviewer abstract screening missed $3 \%$ of relevant studies., We dually screened $50 \%$ of the titles and abstracts, while we used single-screening for the rest. We would like to emphasize that in the central part of the paper, where the detailed review of the selected paper takes place, two reviewers worked independently, while the third reviewer monitored the accuracy of the data. Another limitation relates to the interpretation of the term nautical/maritime/marine tourism, i.e., recreational navigation, boating, leisure boating. When searching the WoS base, the keywords boating/leisure boating/boat/recreational boating/recreational boat were used. The authors [120] point out the same problem in their research, as there are different word interpretation of this type of tourism: nautical, maritime or marine. The lack of a precise definition can be a cause for concern, especially if it includes activities that fall within the scope of national legislation. In view of this, it is possible that we have missed some of the research due to the difference in word interpretation. Nevertheless, bearing this in mind, we believe that none of these limitations would change the overall conclusions of this review. 
Supplementary Materials: The following are available online at https:/ / www.mdpi.com/article/ 10.3390/su131910552/s1, Table S1: Overview of publications which deals with recreational boating and its impact on environment-full version.

Author Contributions: Conceptualization, H.U.B.; methodology, H.U.B.; software, H.U.B.; validation, H.U.B., M.S. and N.G.; formal analysis, H.U.B. and M.S.; investigation, H.U.B. and M.S.; resources, H.U.B.; data curation, H.U.B., M.S., and N.G.; writing-original draft preparation, H.U.B., M.S. and N.G.; writing—review and editing, H.U.B., M.S. and N.G.; visualization, H.U.B.; supervision, N.G. All authors have read and agreed to the published version of the manuscript.

Funding: This research received no external funding.

Institutional Review Board Statement: Not applicable.

Informed Consent Statement: Not applicable.

Data Availability Statement: Data extracted from the WoS search, and data used for the analyses will be available upon request to the corresponding author.

Conflicts of Interest: The authors declare no conflict of interest.

\section{References}

1. Tourism in the 2030 Agenda. Available online: https://www.unwto.org/tourism-in-2030-agenda (accessed on 25 January 2021).

2. Dietvorst, A.G.; Ashworth, G.J. Tourist Behaviour and the Importance of Time-Space Analysis. In Tourism and Spatial Transformations; CAB International: Wallingford, UK, 1995.

3. Shaw, G.; Williams, A.M. Tourism and Tourism Spaces; Sage: Thousand Oaks, CA, USA, 2004. [CrossRef]

4. Lew, A.; McKercher, B. Modeling Tourist Movements. Ann. Tour. Res. 2006, 33, 403-423. [CrossRef]

5. Cui, Y. Identifying Recreational Boater Travel Pattern Using Internet-Based Map. In Travel and Tourism Research Association: Advancing Tourism Research Globally; Michigan State University: East Lansing, MI, USA, 2016.

6. Thornton, P.R.; Williams, A.M.; Shaw, G. Revisiting Time-Space Diaries: An Exploratory Case Study of Tourist Behaviour in Cornwall, England. Environ. Plan. A Econ. Space 1997, 29, 1847-1867. [CrossRef]

7. Page, M.J.; E McKenzie, J.; Bossuyt, P.M.; Boutron, I.; Hoffmann, T.C.; Mulrow, C.D.; Shamseer, L.; Tetzlaff, J.M.; Akl, E.A.; Brennan, S.E.; et al. The PRISMA 2020 statement: An updated guideline for reporting systematic reviews. BMJ 2021, 372, n71. [CrossRef] [PubMed]

8. Gray, D.L.; Canessa, R.R.; Keller, C.P.; Dearden, P.; Rollins, R.B. Spatial characterization of marine recreational boating: Exploring the use of an on-the-water questionnaire for a case study in the Pacific Northwest. Mar. Policy 2011, 35, 286-298. [CrossRef]

9. Gray, D.L.; Canessa, R.; Rollins, R.; Keller, C.P.; Dearden, P. Incorporating Recreational Users into Marine Protected Area Planning: A Study of Recreational Boating in British Columbia, Canada. Environ. Manag. 2010, 46, 167-180. [CrossRef] [PubMed]

10. Acosta, H.; Wu, D.; Forrest, B.M. Fuzzy experts on recreational vessels, a risk modelling approach for marine invasions. Ecol. Model. 2010, 221, 850-863. [CrossRef]

11. Mari, L.; Bertuzzo, E.; Casagrandi, R.; Gatto, M.; Levin, S.; Rodriguez-Iturbe, I.; Rinaldo, A. Hydrologic controls and anthropogenic drivers of the zebra mussel invasion of the Mississippi-Missouri river system. Water Resour. Res. 2011, 47. [CrossRef]

12. Grossmann, M. Impacts of boating trip limitations on the recreational value of the Spreewald wetland: A pooled revealed/contingent behaviour application of the travel cost method. J. Environ. Plan. Manag. 2011, 54, 211-226. [CrossRef]

13. Muirhead, J.R.; MacIsaac, H.J. Evaluation of stochastic gravity model selection for use in estimating non-indigenous species dispersal and establishment. Biol. Invasions 2011, 13, 2445-2458. [CrossRef]

14. Muirhead, J.R.; Lewis, M.; MacIsaac, H.J. Prediction and error in multi-stage models for spread of aquatic non-indigenous species. Divers. Distrib. 2011, 17, 323-337. [CrossRef]

15. David, J.A. Theoretical approach to estimating the induction of hearing impairment in bottlenose dolphins by radiated leisure boat noise. J. Mar. Biol. Assoc. U. K. 2011, 92, 1887-1892. [CrossRef]

16. Chivers, C.; Leung, B. Predicting invasions: Alternative models of human-mediated dispersal and interactions between dispersal network structure and Allee effects. J. Appl. Ecol. 2012, 49, 1113-1123. [CrossRef]

17. Lacoursière-Roussel, A.; Forrest, B.M.; Guichard, F.; Piola, R.F.; McKindsey, C. Modeling biofouling from boat and source characteristics: A comparative study between Canada and New Zealand. Biol. Invasions 2012, 14, 2301-2314. [CrossRef]

18. Tett, P.; Valcic, B.; Potts, T.; Whyte, C.; Culhane, F.; Fernandes, T. Mussels and Yachts in Loch Fyne, Scotland: A Case Study of the Science-Policy Interface. Ecol. Soc. 2012, 17. [CrossRef]

19. Hallac, D.E.; Sadle, J.; Pearlstine, L.; Herling, F.; Shinde, D. Boating impacts to seagrass in Florida Bay, Everglades National Park, Florida, USA: Links with physical and visitor-use factors and implications for management. Mar. Freshw. Res. 2012, 63, 1117-1128. [CrossRef]

20. Fujitani, M.L.; Fenichel, E.; Torre, J.; Gerber, L.R. Implementation of a marine reserve has a rapid but short-lived effect on recreational angler use. Ecol. Appl. 2012, 22, 597-605. [CrossRef] [PubMed] 
21. Kang, N.S.; Shin, I.S.; Yoon, H.H. A conceptual study for the development of a leisure boat simulator. In Proceedings of the 2013 The International Conference on Technological Advances in Electrical, Electronics and Computer Engineering (TAEECE), Konya, Turkey, 9-11 May 2013; pp. 354-358. [CrossRef]

22. Murray, C.C.; Therriault, T.W.; Pakhomov, E. What Lies Beneath? An Evaluation of Rapid Assessment Tools for Management of Hull Fouling. Environ. Manag. 2013, 52, 374-384. [CrossRef]

23. Lorenz, S.; Gabel, F.; Dobra, N.; Pusch, M.T. Modelling the effects of recreational boating on self-purification activity provided by bivalve mollusks in a lowland river. Freshw. Sci. 2013, 32, 82-93. [CrossRef]

24. Diedrich, A.; Terrados, J.; Arroyo, N.L.; Balaguer, P. Modeling the influence of attitudes and beliefs on recreational boaters' use of buoys in the Balearic Islands. Ocean. Coast. Manag. 2013, 78, 112-120. [CrossRef]

25. Longley, K.; Lipsky, A. Human Use Characterization and Visualization in Marine Spatial Planning Efforts in the Northeast I IEEE Conference Publication I IEEE Xplore. In Proceedings of the 2013 OCEANS, San Diego, CA, USA, 23-27 September 2013; pp. 1-8.

26. Jett, J.; Thapa, B.; Swett, R. Boater Speed Compliance in Manatee Zones: Examining a Proposed Predictive Model. Soc. Nat. Resour. 2013, 26, 95-104. [CrossRef]

27. Farr, M.; Stoeckl, N.; Sutton, S. Recreational fishing and boating: Are the determinants the same? Mar. Policy 2014, $47,126-137$. [CrossRef]

28. Loomis, J.; McTernan, J. Economic Value of Instream Flow for Non-Commercial Whitewater Boating Using Recreation Demand and Contingent Valuation Methods. Environ. Manag. 2014, 53, 510-519. [CrossRef]

29. Raffaele, G. Statistical Nomogram for the Evaluation of Berth Activities in Port Areas. Procedia Econ. Finance 2014, 17, 165-174. [CrossRef]

30. Roe, P.; Hrymak, V.; Dimanche, F. Assessing environmental sustainability in tourism and recreation areas: A risk-assessment-based model. J. Sustain. Tour. 2013, 22, 319-338. [CrossRef]

31. Pieralice, F.; Proietti, R.; La Valle, P.; Giorgi, G.; Mazzolena, M.; Taramelli, A.; Nicoletti, L. An innovative methodological approach in the frame of Marine Strategy Framework Directive: A statistical model based on ship detection SAR data for monitoring programmes. Mar. Environ. Res. 2014, 102, 18-35. [CrossRef] [PubMed]

32. Davidson, A.D.; Fusaro, A.J.; Kashian, D.R. Using a Novel Spatial Tool to Inform Invasive Species Early Detection and Rapid Response Efforts. Environ. Manag. 2015, 56, 54-65. [CrossRef] [PubMed]

33. Wittmann, M.E.; Kendall, B.; Jerde, C.L.; Anderson, L.W. Estimating relative risk of within-lake aquatic plant invasion using combined measures of recreational boater movement and habitat suitability. PeerJ 2015, 3, e845. [CrossRef] [PubMed]

34. Cui, Y.; Chang, W.-H.; Mahoney, E. Economic Impacts of Recreational Use of Inland Waterways in US. Int. J. Transp. Econ. 2015, 42, 171-190.

35. Lee, D.; Du Preez, M. A demand-based management option to address boat congestion at the Sundays River Estuary, Eastern Cape, South Africa. Water SA 2015, 41, 579. [CrossRef]

36. Morandi, M.; Manning, N.; Bossenbroek, J.; Jerde, C. Assessing the influence of different inland lake management strategies on human-mediated invasive species spread. Manag. Biol. Invasions 2015, 6, 57-69. [CrossRef]

37. Lee, D.E.; Hosking, S.G.; Du Preez, M. Managing Some Motorised Recreational Boating Challenges in South African Estuaries: A Case Study at the Kromme River Estuary. S. Afr. J. Econ. 2014, 83, 286-302. [CrossRef]

38. Stewart-Koster, B.; Olden, J.; Johnson, P.T.J. Integrating landscape connectivity and habitat suitability to guide offensive and defensive invasive species management. J. Appl. Ecol. 2015, 52, 366-378. [CrossRef]

39. Ray, C.; Gallen, R.; Iphar, C.; Napoli, A.; Bouju, A. DeAIS project: Detection of AIS spoofing and resulting risks. In Proceedings of the Oceans 2015, Genova, Italy, 21 September 2015; pp. 1-6. [CrossRef]

40. Gon, M.; Osti, L.; Pechlaner, H. Leisure boat tourism: Residents' attitudes towards nautical tourism development. Tour. Rev. 2016, 71, 180-191. [CrossRef]

41. Ferrario, J.; Marchini, A.; Borrelli, P.; Berzolari, F.G.; Occhipinti-Ambrogi, A. A fuzzy 'boater' model to detect fouling and spreading risk of non-indigenous species by recreational boats. J. Environ. Manag. 2016, 182, 198-207. [CrossRef]

42. Pennino, M.G.; Roda, M.A.P.; Pierce, G.; Rotta, A. Effects of vessel traffic on relative abundance and behaviour of cetaceans: The case of the bottlenose dolphins in the Archipelago de La Maddalena, north-western Mediterranean sea. Hydrobiologia 2016, 776, 237-248. [CrossRef]

43. Ziv, G.; Mullin, K.; Boeuf, B.; Fincham, W.; Taylor, N.; Villalobos-Jiménez, G.; Von Vittorelli, L.; Wolf, C.; Fritsch, O.; Strauch, M.; et al. Water Quality Is a Poor Predictor of Recreational Hotspots in England. PLoS ONE 2016, 11, e0166950. [CrossRef]

44. Midwood, J.D.; Darwin, A.; Ho, Z.-Y.; Rokitnicki-Wojcik, D.; Grabas, G. Environmental factors associated with the distribution of non-native starry stonewort (Nitellopsis obtusa) in a Lake Ontario coastal wetland. J. Great Lakes Res. 2016, 42, 348-355. [CrossRef]

45. Curtis, J.; Hynes, S.; Breen, B. Recreational boating site choice and the impact of water quality. Heliyon 2017, 3, e00426. [CrossRef]

46. Viana, D.; Gornik, K.; Lin, C.-C.; McDonald, G.; Ng, N.S.; Quigley, C.; Potoski, M. Recreational boaters value biodiversity: The case of the California Channel Islands National Marine Sanctuary. Mar. Policy 2017, 81, 91-97. [CrossRef]

47. Daehne, D.; Fürle, C.; Thomsen, A.; Watermann, B.; Feibicke, M. Antifouling biocides in German marinas: Exposure assessment and calculation of national consumption and emission. Integr. Environ. Assess. Manag. 2017, 13, 892-905. [CrossRef]

48. Lepoša, N. The emergence of ambivalent leisure consumers-The case of boating along the Swedish West Coast. J. Clean. Prod. 2017, 145, 35-44. [CrossRef] 
49. Chivers, C.; Drake, D.A.R.; Leung, B. Economic effects and the efficacy of intervention: Exploring unintended effects of management and policy on the spread of non-indigenous species. Biol. Invasions 2017, 19, 1795-1810. [CrossRef]

50. Hotaling-Hagan, A.; Swett, R.; Ellis, L.R.; Frazer, T.K. A spatial model to improve site selection for seagrass restoration in shallow boating environments. J. Environ. Manag. 2017, 186, 42-54. [CrossRef] [PubMed]

51. Itami, R.M.; Gimblett, R.; Poe, A. Level of Sustainable Activity: A Framework for Integrating Stakeholders into the Simulation Modeling and Management of Mixed-Use Waterways. In Environmental Modeling with Stakeholders: Theory, Methods, and Applications; Springer: Cham, Switzerland, 2016; pp. 211-239. [CrossRef]

52. Jain-Schlaepfer, S.M.R.; Blouin-Demers, G.; Cooke, S.J.; Bulté, G. Do boating and basking mix? The effect of basking disturbances by motorboats on the body temperature and energy budget of the northern map turtle. Aquat. Conserv. Mar. Freshw. Ecosyst. 2016, 27, 547-558. [CrossRef]

53. Parsons, G.R. Travel Cost Models; Springer: Dordrecht, The Netherlands, 2017; pp. 187-233. [CrossRef]

54. Montes, N.; Swett, R.; Jacobson, S.K.; Sidman, C. Factors Influencing Recreational Boaters' Intentions to Comply with Right Whale Regulations in the Southeastern United States. Soc. Nat. Resour. 2017, 31, 473-488. [CrossRef]

55. Han, J.H.; Oh, C.-O. The Causal Mechanisms of Environmentally Responsible Behaviors Using Value Orientations and Recreation Specialization. Leis. Sci. 2018, 43, 471-493. [CrossRef]

56. Montes, N.; Swett, R.; Ahrens, R. Modeling the spatial and seasonal distribution of offshore recreational vessels in the southeast United States. PLoS ONE 2018, 13, e0208126. [CrossRef] [PubMed]

57. Hunt, L.M.; Morris, D.M.; Drake, D.A.R.; Buckley, J.D.; Johnson, T.B. Predicting spatial patterns of recreational boating to understand potential impacts to fisheries and aquatic ecosystems. Fish. Res. 2018, 211, 111-120. [CrossRef]

58. Pelletier-Rousseau, M.; Bernier, R.; Murray, C.C.; Drolet, D.; Lacoursière-Roussel, A.; Locke, A.; Martin, J.L.; McKenzie, C.H.; McKindsey, C.; Therriault, T.W.; et al. Assessment of recreational boating as a vector for marine non-indigenous species on the Atlantic coast of Canada. Biol. Invasions 2019, 21, 2447-2470. [CrossRef]

59. Alvarez, S.; Lupi, F.; Solís, D.; Thomas, M. Valuing Provision Scenarios of Coastal Ecosystem Services: The Case of Boat Ramp Closures Due to Harmful Algae Blooms in Florida. Water 2019, 11, 1250. [CrossRef]

60. Hermannsen, L.; Mikkelsen, L.; Tougaard, J.; Beedholm, K.; Johnson, M.; Madsen, P. Recreational vessels without Automatic Identification System (AIS) dominate anthropogenic noise contributions to a shallow water soundscape. Sci. Rep. 2019, 9, 1-10. [CrossRef] [PubMed]

61. Abu Hanipah, A.; Guo, Z. Reaeration Caused by Intense Boat Traffic. Asian J. Water, Environ. Pollut. 2019, 16, 15-24. [CrossRef]

62. Bigerna, S.; Micheli, S.; Polinori, P. Willingness to pay for electric boats in a protected area in Italy: A sustainable tourism perspective. J. Clean. Prod. 2019, 224, 603-613. [CrossRef]

63. Johansson, L.; Ytreberg, E.; Jalkanen, J.-P.; Fridell, E.; Eriksson, K.M.; Lagerström, M.; Maljutenko, I.; Raudsepp, U.; Fischer, V.; Roth, E. Model for leisure boat activities and emissions-Implementation for the Baltic Sea. Ocean. Sci. 2020, 16, $1143-1163$. [CrossRef]

64. Dalton, T.; Weir, M.; Calianos, A.; D'Aversa, N.; Livermore, J. Recreational boaters' preferences for boating trips associated with offshore wind farms in US waters. Mar. Policy 2020, 122, 104216. [CrossRef]

65. Marušić, E.; Šoda, J.; Krčum, M. The Three-Parameter Classification Model of Seasonal Fluctuations in the Croatian Nautical Port System. Sustainability 2020, 12, 5079. [CrossRef]

66. Vieira, M.; Amorim, M.C.P.; Sundelöf, A.; Prista, N.; Fonseca, P. Underwater noise recognition of marine vessels passages: Two case studies using hidden Markov models. ICES J. Mar. Sci. 2019, 77, 2157-2170. [CrossRef]

67. Alós, J.; Lana, A.; Ramis, J.; Arlinghaus, R. Interactions between angler movement behaviour and an invasive seaweed with ecosystem engineering properties in a marine recreational fishery. Fish. Res. 2020, 230, 105624. [CrossRef]

68. Parretti, P.; Canning-Clode, J.; Ferrario, J.; Marchini, A.; Botelho, A.Z.; Ramalhosa, P.; Costa, A.C. Free rides to diving sites: The risk of marine non-indigenous species dispersal. Ocean. Coast. Manag. 2020, 190, 105158. [CrossRef]

69. Kuentzel, W.F.; Heberlein, T.A.; Mccollum, D.W. Why do normative encounter standards change? The social evolution of recreational crowding. J. Leis. Res. 2020, 1-20. [CrossRef]

70. Palomo, L.E.; Hernández-Flores, A. Integrating a spatial model and decision theory towards optimal boating density and carrying capacity in a recreational fishery. Mar. Policy 2019, 112, 103740. [CrossRef]

71. La Manna, G.; Ronchetti, F.; Sarà, G.; Ruiu, A.; Ceccherelli, G. Common Bottlenose Dolphin Protection and Sustainable Boating: Species Distribution Modeling for Effective Coastal Planning. Front. Mar. Sci. 2020, 7, 955. [CrossRef]

72. Lagerström, M.; Ferreira, J.; Ytreberg, E.; Eriksson-Wiklund, A.-K. Flawed risk assessment of antifouling paints leads to exceedance of guideline values in Baltic Sea marinas. Environ. Sci. Pollut. Res. 2020, 27, 27674-27687. [CrossRef] [PubMed]

73. Kendall, M.S.; Williams, B.L.; Winship, A.J.; Carson, M.; Grissom, K.; Rowell, T.J.; Stanley, J.; Roberson, K.W. Winds, waves, warm waters, weekdays, and which ways boats are counted influence predicted visitor use at an offshore fishing destination. Fish. Res. 2021, 237, 105879. [CrossRef]

74. Chapagain, B.P.; Poudyal, N.C.; Bowker, J.M.; E Askew, A.; English, D.B.K.; Hodges, D.G. Demand for and Economic Value of Nonmotorized Boating Access in Rivers at US National Forests. J. For. 2021, 119, 275-290. [CrossRef]

75. Kao, S.-Y.Z.; Enns, E.A.; Tomamichel, M.; Doll, A.; Escobar, L.E.; Qiao, H.; Craft, M.E.; Phelps, N.B.D. Network connectivity of Minnesota waterbodies and implications for aquatic invasive species prevention. Biol. Invasions 2021, 1-12. [CrossRef] 
76. Participants in Sailing, U.S. 2019 | Statista. Available online: https:/ /www.statista.com/statistics/191300/participants-in-sailingin-the-us-since-2006/ (accessed on 16 July 2021).

77. Industry, E.B. Facts \& figures. Available online: https://www.europeanboatingindustry.eu/about-the-industry/facts-and-figures (accessed on 16 July 2021).

78. RTI International. National Recreational Boating Survey Report; RTI International: Triangle Park, NC, USA, 2020.

79. U.S. Coast Guard. National Recreational Boating Survey Report; U.S. Coast Guard: Washington, DC, USA, 2012.

80. U.S. Coast Guard. National Recreational Boating Survey Report; U.S. Coast Guard: Washington, DC, USA, 2011.

81. Strategic Research Group. 2002 National Recreational Boating Survey; Strategic Research Group: London, UK, 2002.

82. Montes Osorio de Soto, N. Analyzing the Distribution of Recreational Boating off the Coast of Northeast Florida to Determine Implications for the Conservation of the North Atlantic Right Whale; University of Florida: Gainesville, FL, USA, 2016.

83. Montes, N.; Swett, R.; Sidman, C.; Fik, T. Offshore Recreational Boating Characterization in the Southeast US; Florida Sea Grant TP-226: Gainesville, FL, USA, 2016.

84. O'Mahony, C.; Gault, J.; Cummins, V.; Kopke, K.; O'Suilleabhain, D. Assessment of recreation activity and its application to integrated management and spatial planning for Cork Harbour, Ireland. Mar. Policy 2009, 33, 930-937. [CrossRef]

85. Kopke, K.; O’Mahony, C.; Cummins, V.; Gault, J. Assessment of Coastal Recreational Activity and Capacity for Increased Boating in Cork Harbour; University College Cork: Cork, Ireland, 2006.

86. Cummins, V.; Gault, J.; O’Mahony, C.; Kopke, K.; Griffin, P.; Walsh, E.; O'Suilleabhain, D. Establishing Information Needs for Planning and Assessment of Recreation Activity in the Coastal Environment: A Case Study from Cork Harbour, Ireland. In Proceedings of the International Pluridisciplinary Conference “The Littoral: Challenge, Dialogue, Action", Lille, France, 16-18 January 2008; pp. 16-18.

87. Swedish Transport Agency. Recreational Boating Survey 2015; Swedish Transport Agency: Norrkoping, Sweden, 2016.

88. Ministry of Tourism. TOMAS NAUTIKA JAHTING 2012; Ministry of Tourism: Stockholm, Sweden, 2012.

89. Marušić, Z.; Horak, S.; Sever, I. REZULTATI ISTRAŽIVANJA Republika Hrvatska Ministarstvo Turizma; Ministry of Tourism: Stockholm, Sweden, 2018.

90. Byrnes, T.A.; Dunn, R.J.K. Boating- and Shipping-Related Environmental Impacts and Example Management Measures: A Review. J. Mar. Sci. Eng. 2020, 8, 908. [CrossRef]

91. González, D.A.; Campanales, S.; Grimalt, M. Managing the environmental sustainability of nautical tourism in Mediterranean MPAs. Capboating Project. Edited by eco-union. 24 pages. Managing the Environmental Sustainability of Nautical Tourism in Mediterranean Marine Protected Areas. 2020. Available online: http:/ /www.ecounion.eu/wp-content/uploads/2020/07/ Boading-Guidelines_3_7_20.pdf (accessed on 20 June 2021).

92. European Comission. Science for Environment Policy. Environmental Impacts of Recreational Boating; European Comission: Geneva, Switzerland, 2007.

93. Moreau, R. Nautical Activities. What Impact on the Environment? A Life Cycle Approach for "Clear Blue" Boating-Commissioned by the European Confederation Of Nautical Industries-ECNI, 2nd ed.; Moreau, R., Jansen, P., Mayer, H., Roeder, I.K., Wittamore, K., Eds.; European Confederation of Nautical Industries: Brusseles, Belgium, 2009.

94. Byrnes, T.; Warnken, J. Greenhouse Gas Emissions from Marine Tours: A Case Study of Australian Tour Boat Operators. J. Sustain. Tour. 2006, 14, 255-270. [CrossRef]

95. Cindric, A.-M.; Garnier, C.; Oursel, B.; Pižeta, I.; Omanović, D. Evidencing the natural and anthropogenic processes controlling trace metals dynamic in a highly stratified estuary: The Krka River estuary (Adriatic, Croatia). Mar. Pollut. Bull. 2015, 94, 199-216. [CrossRef]

96. MedPAN Organization. NaTEF-Nautical Torusim Ecological Footprint in MPAs. Available online: https://sites.google.com/ view / natef/ (accessed on 2 February 2020).

97. Carić, H.; Cukrov, N.; Omanović, D. Nautical Tourism Ecological Footprinting (NatEF)—Experiences from East Adriatic in Developing Assessments. In Proceedings of the The 9th International Conference on Monitoring and Management of Visitors in Recreational and Protected Areas (MMV9), Bordeaux, France, 29-31 August 2018; p. 500.

98. Valkirs, A.; Seligman, P.F.; Haslbeck, E.; Caso, J.S. Measurement of copper release rates from antifouling paint under laboratory and in situ conditions: Implications for loading estimation to marine water bodies. Mar. Pollut. Bull. 2003, 46, 763-779. [CrossRef]

99. Thomas, K.; Raymond, K.; Chadwick, J.; Waldock, M. The effects of short-term changes in environmental parameters on the release of biocides from antifouling coatings: Cuprous oxide and tributyltin. Appl. Organomet. Chem. 1999, 13, 453-460. [CrossRef]

100. Lloret, J.; Zaragoza, N.; Caballero, D.; Riera, V. Impacts of recreational boating on the marine environment of Cap de Creus (Mediterranean Sea). Ocean. Coast. Manag. 2008, 51, 749-754. [CrossRef]

101. Milazzo, M.; Badalamenti, F.; Ceccherelli, G.; Chemello, R. Boat anchoring on Posidonia oceanica beds in a marine protected area (Italy, western Mediterranean): Effect of anchor types in different anchoring stages. J. Exp. Mar. Biol. Ecol. 2004, 299, 51-62. [CrossRef]

102. Jelić Mrčelić, G.; Slišković, M. Environmentally Responsible Nautical Tourism And Related Services. 2020. Available online: https:/ / www.italy-croatia.eu/documents / 292735/0/ curriculum+web+07.07..pdf/70368742-9002-2d24-1b0f-0d2ff8b5d9 $21 ? \mathrm{t}=1594103588798$ (accessed on 20 June 2021).

103. Sagerman, J.; Hansen, J.P.; Wikström, S.A. Effects of boat traffic and mooring infrastructure on aquatic vegetation: A systematic review and meta-analysis. Ambio 2019, 49, 517-530. [CrossRef] [PubMed] 
104. Koboević, Z.; Kurtela, Z.; Koboević, N. Risk Assessment Model of Coastal Sea Pollution by Black (Sewage) Waters From Vessels. Int. J. Marit. Eng. 2018, 160, A4. [CrossRef]

105. Park priode Lastovsko otočje, Sidrišta-Javna ustanova “Park Prirode Lastovsko otočje". Available online: http://pp-lastovo.hr/ sidrista / (accessed on 16 September 2021).

106. Healthy Land and Water. Environmentally Friendly Moorings-Healthy Land and Water. Available online: https://hlw.org.au/ project/environmentally-friendly-moorings/\#tabs-1 (accessed on 16 September 2021).

107. EMSA. European Maritime Safety Agency-Traffic Density Mapping Service (TDMS). Available online: http://www.emsa.europa. eu/related-projects/tdms.html (accessed on 19 February 2021).

108. Wu, L.; Xu, Y.; Wang, Q.; Wang, F.; Xu, Z. Mapping Global Shipping Density from AIS Data. J. Navig. 2016, 70, 67-81. [CrossRef]

109. Al-Sobky, A.-S.A.; Mousa, R.M. Traffic density determination and its applications using smartphone. Alex. Eng. J. 2016, 55, 513-523. [CrossRef]

110. EMODnet. Vessel Density Map—Detailed Method. 2019. Available online: https://www.emodnet-humanactivities.eu/ documents/Vessel\%20density\%20maps_method_v1.5.pdf (accessed on 20 June 2021).

111. Arguedas, V.F.; Pallotta, G.; Vespe, M. Maritime Traffic Networks: From Historical Positioning Data to Unsupervised Maritime Traffic Monitoring. IEEE Trans. Intell. Transp. Syst. 2017, 19, 722-732. [CrossRef]

112. Arguedas, V.F.; Pallotta, G.; Vespe, M. Automatic Generation of Geographical Networks for Maritime Traffic Surveillance. In Proceedings of the FUSION 2014-17th International Conference on Information Fusion, Salamanca, Spain, 7-10 August 2014.

113. Pallotta, G.; Vespe, M.; Bryan, K. Vessel Pattern Knowledge Discovery from AIS Data: A Framework for Anomaly Detection and Route Prediction. Entropy 2013, 15, 2218-2245. [CrossRef]

114. Pallotta, G.; Vespe, M.; Bryan, K. Traffic Knowledge Discovery from AIS Data. In Proceedings of the 16th International Conference on Information Fusion, Rustenburg, South Africa, 6-9 July 2013.

115. Zhang, S.-K.; Liu, Z.-J.; Cai, Y.; Wu, Z.-L.; Shi, G.-Y. AIS Trajectories Simplification and Threshold Determination. J. Navig. 2015, 69, 729-744. [CrossRef]

116. Willems, C.N.; van de Wetering, H.; Van Wijk, J.J. Visualization of vessel movements. Comput. Graph. Forum 2009, 28, 959-966. [CrossRef]

117. Zhao, L.; Shi, G. A method for simplifying ship trajectory based on improved Douglas-Peucker algorithm. Ocean. Eng. 2018, 166, 37-46. [CrossRef]

118. Butowski, L. An integrated AHP and PROMETHEE approach to the evaluation of the attractiveness of European maritime areas for sailing tourism. Morav. Geogr. Rep. 2018, 26, 135-148. [CrossRef]

119. Gartlehner, G.; Affengruber, L.; Titscher, V.; Noel-Storr, A.; Dooley, G.; Ballarini, N.; König, F. Single-reviewer abstract screening missed 13 percent of relevant studies: A crowd-based, randomized controlled trial. J. Clin. Epidemiol. 2020, 121, 20-28. [CrossRef] [PubMed]

120. Vázquez, R.M.M.; García, J.M.; Valenciano, J.D.P. Analysis and Trends of Global Research on Nautical, Maritime and Marine Tourism. J. Mar. Sci. Eng. 2021, 9, 93. [CrossRef] 